DOI: $10.5604 / 01.3001 .0012 .5293$

\title{
DWA RÓWNOLEGLE POMIARY WIETRZNOŚCI JAKO DOKŁADNA OCENA LOKALNYCH ZASOBÓW ENERGII WIATRU
}

\author{
Piotr Gnyp \\ Politechnika Śląska, Wydział Inżynierii Środowiska i Energetyki
}

Streszczenie. Pomiary wietrzności przeprowadzono przy użyciu dwóch masztów pomiarowych oddalonych od siebie o 17,6 km. Wyznaczono dwa numeryczne modele terenu - numeryczny model wysokościowy terenu oraz numeryczny model szorstkości terenu. Podczas analizy danych pomiarowych zauważono znaczące różnice $w$ zmierzonej prędkości wiatru pomiędzy masztami pomiarowymi. Dodatkowy pomiar wietrzności może okazać się niezbędny dla uzyskania petnej informacji o charakterze wietrzności dla danej lokalizacji.

Słowa kluczowe: pomiar wietrzności, numeryczny model wysokościowy terenu, numeryczny model szorstkości terenu, systemy informacji geograficznej

\section{TWO PARALLEL WIND MEASUREMENTS AS AN ACCURATE ASSESSMENT OF LOCAL WIND ENERGY RESOURCES}

\begin{abstract}
The wind measurements were made using two measuring masts spaced $17.6 \mathrm{~km}$ apart. Two numerical terrain models were identified - the numerical terrain model and the numerical roughness model. During measurement data analysis significant differences in measured wind speed between measuring masts were noted. Additional wind measurements may be necessary to obtain complete wind quality information for the location.
\end{abstract}

Keywords: wind measurement, digital elevation model, surface roughness, geographic information systems

\section{Wstęp}

Obecnie, aby przeprowadzić proces inwestycyjny mający na celu wybudowanie farmy wiatrowej, niezbędne jest przeprowadzenie lokalnych pomiarów wietrzności. Pomiar wietrzności powinien trwać minimum rok, aby uchwycić jego sezonową zmienność. W miesiącach letnich występują niższe wartości prędkości wiatru ze względu na okres wegetacyjny roślin. Na niższe prędkości wiatru ma wpływ zwiększona szorstkość terenu spowodowana rozwojem roślinności. Na zmianę prędkości wiatru poza rozwojem roślinności mają wpływ ukształtowanie i pokrycie terenu $[5,9]$.

Aby poznać rzeczywiste warunki wiatrowe, należy sprawdzić nie tylko ich sezonową zmienność ale zróżnicowanie rozkładu wiatru spowodowane charakterystyką terenu. W celu dokładnej oceny warunków wietrzności, jeden maszt pomiarowy może stać się niewystraczający i należy przeprowadzić dodatkowy, jednoczesny pomiar wietrzności. Takie podejście pozwoli poznać zmiany w prędkości i kierunku wiatru spowodowane zmianami orografii i szorstkości terenu [2].

Analizowana lokalizacja i miejsce przeprowadzenia badań znajdowało się w pasie nadmorskim (okolice Słupska). W tych rejonach odnotowuje się najwyższe średnioroczne prędkości wiatru. Analiza danych pomiarowych została wykonana w oprogramowaniu dla energetyki wiatrowej WindPRO, natomiast analiza ukształtowania i pokrycia terenu w oprogramowaniu GIS Global Mapper [3, 7].

\section{Aparatura pomiarowa}

Pomiar wietrzności został przeprowadzony przy użyciu dwóch masztów pomiarowych zlokalizowanych w województwie pomorskim (okolice Słupska). Każdy z masztów miał wysokość $100 \mathrm{~m}$ i zbierał dane w okresie:

- Maszt pomiarowy M1 - (15.03.2011 - 30.06.2014),

- $\quad$ Maszt pomiarowy M2 - (15.03.2011 - 30.06.2014).

Dane pomiarowe zostały rejestrowane przy użyciu aparatury pomiarowej na którą składały się anemometry, wiatrowskazy oraz urządzenie rejestrujące wyposażone w moduł GSM do transmisji danych. W tabeli 1 zestawiono dane dotyczące lokalizacji masztów pomiarowych M1 i M2, natomiast w tabeli 2 ich konfigurację. Rysunek 1 ilustruje położenie masztów pomiarowych M1 i M2 na tle województwa pomorskiego. Rysunki 2 i 3 przedstawiają szczegółowe położenie masztów pomiarowych na tle map lotniczych [16].
Konfiguracja masztów pomiarowych została dobrana zgodnie z zaleceniami organizacji Measnet. Wszystkie czujniki rejestrujące cechowały się wysoką dokładnością, zostały poddane kalibracji przed i po zakończonym okresie pomiarowym. Do rejestrowania prędkości wiatru wybrano wysokiej klasy anemometry Thies First Class Advanced, zgodne z normą PN-EN 61400-12-1. Zakres pomiaru anemometrów Thies First Class Advanced to przedział $0,3-75 \mathrm{~m} / \mathrm{s}$ przy linowości pomiaru wynoszącym $r=0,999(w$ przedziale $4-20 \mathrm{~m} / \mathrm{s})$ [10, 11, 14].

Tabela 1. Dane dotyczace lokalizacji masztów pomiarowych M1 i M2

\begin{tabular}{|c|c|c|}
\hline Maszt pomiarowy & M1 & M2 \\
\hline Województwo & \multicolumn{2}{|c|}{ pomorskie } \\
\hline Powiat & \multicolumn{2}{|c|}{ Słupsk } \\
\hline Gmina & \multicolumn{2}{|c|}{ Słupsk } \\
\hline \multirow{2}{*}{ Współrzędne lokalizacji } & $17^{\circ} 06^{\prime} 27,20^{\prime \prime} \mathrm{E}$ & $17^{\circ} 19^{\prime} 50,60^{\prime \prime} \mathrm{E}$ \\
& $54^{\circ} 31^{\prime} 56,00^{\prime \prime} \mathrm{N}$ & $54^{\circ} 26^{\prime} 34,40^{\prime \prime} \mathrm{N}$ \\
\hline Wysokość lokalizacji & $68 \mathrm{~m}$ n. p. m. & $76 \mathrm{~m}$ n. p. m. \\
\hline
\end{tabular}

Tabela 2. Dane dotyczące konfiguracji masztów pomiarowych M1 i M2

\begin{tabular}{|c|c|c|}
\hline Maszt pomiarowy & M1 & M2 \\
\hline Województwo & \multicolumn{2}{|c|}{ Wysokość instalacji [m] } \\
\hline Anemometr 1 & 100,0 & 100,0 \\
\hline Anemometr 2 & 98,5 & 98,5 \\
\hline Anemometr 3 & 74,0 & 74,0 \\
\hline Anemometr 4 & 40,0 & 40,0 \\
\hline Wiatrowskaz 1 & 98,5 & 98,5 \\
\hline Wiatrowskaz 2 & 40,0 & 40,0 \\
\hline
\end{tabular}

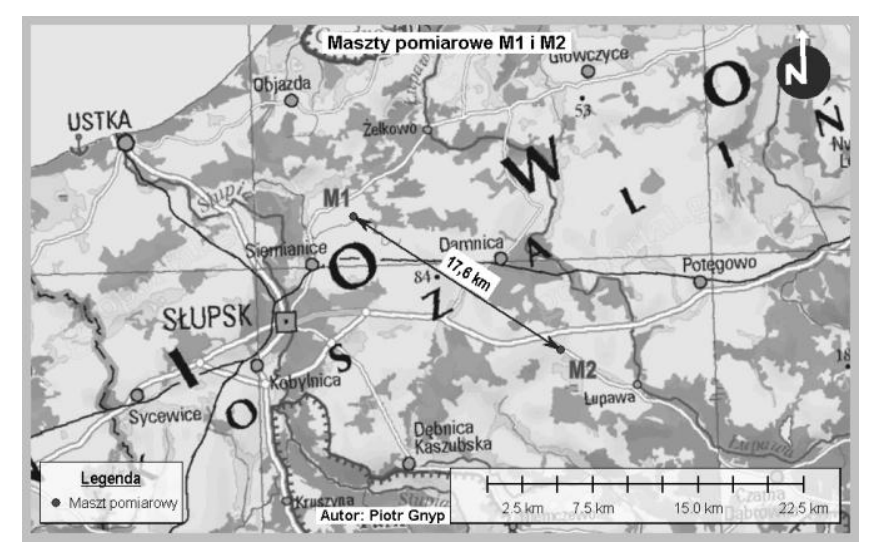

Rys. 1. Położenie masztów pomiarowych M1 i M2 na tle województwa pomorskiego 


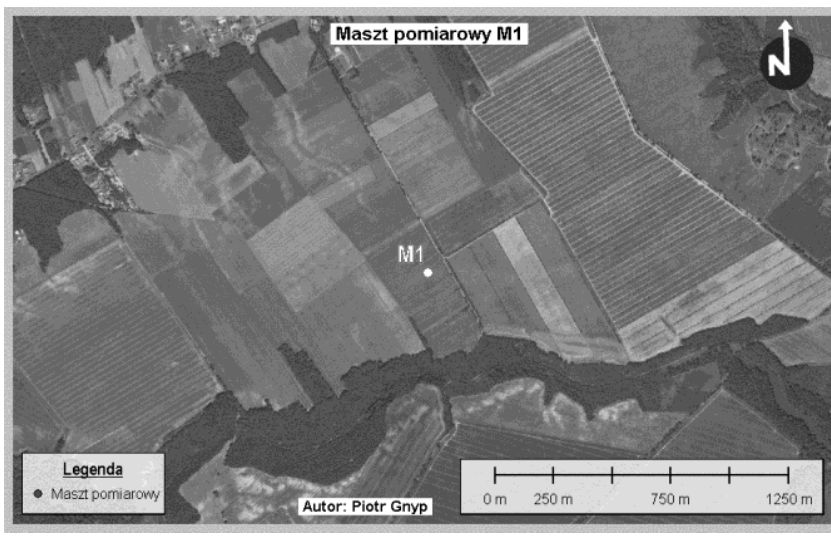

Rys. 2. Szczegótowe położenie masztu pomiarowego MI

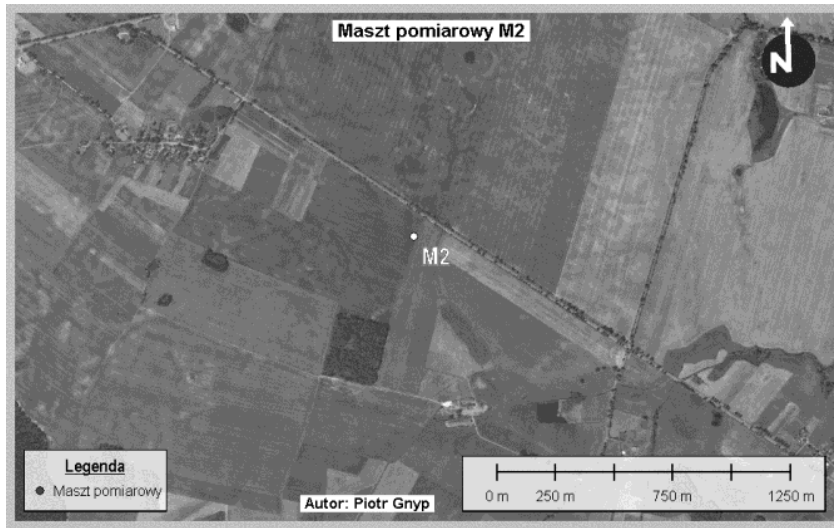

Rys. 3. Szczegółowe położenie masztu pomiarowego M2

Do pomiaru kierunku wiatru zastosowano potencjometryczny wiatrowskaz Thies Compact o zakresie pomiaru $0-360^{\circ}$. Rozdzielczość pomiaru wynosi $0,5^{\circ}$ przy dokładności $2^{\circ}$ [12].

Do rejestrowania danych pomiarowych wybrano urządzenie rejestrujące Ammonit Meteo-32, charakteryzujące się możliwością podłączenia do 10 czujników pomiarowych. Rejestrator Ammonit Meteo-32 posiada możliwość rejestrowania danych na karcie pamięci oraz możliwość podłączenia modułu GSM do transmisji danych [13].

Rysunki 4 i 5 ilustrują zastosowane czujniki pomiarowe a rysunek 6 - urządzenie rejestrujące Ammonit Meteo-32.

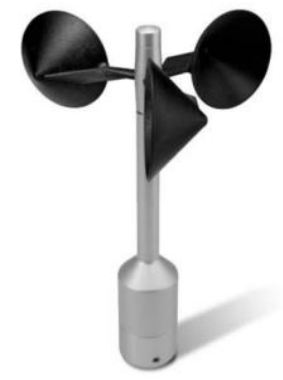

Rys. 4. Anemometr Thies First Class Advanced [11]

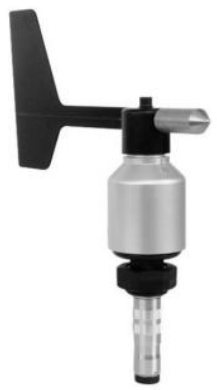

Rys. 5. Wiatrowskaz Thies Compact [12]

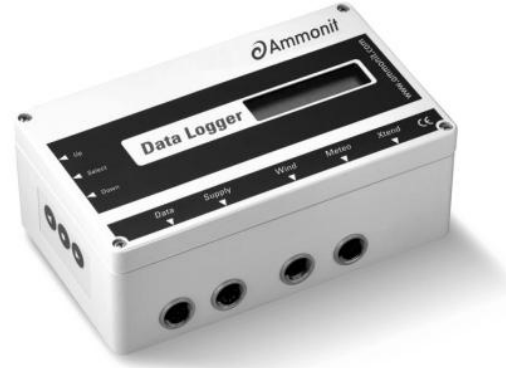

Rys. 6. Urządzenie rejestrujące Ammonit Meteo-32 [13]

\section{Charakterystyka terenu}

Teren wokół masztów pomiarowych można zakwalifikować jako równinny, w większości uprawiany rolniczo $\mathrm{z}$ dużymi zwartymi kompleksami leśnymi. Brak jest wysokich obiektów, które można by zakwalifikować jako przeszkody terenowe zaburzające w sposób istotny przepływającą masę powietrza. Dla analizowanego obszaru określono dwa numeryczne modele terenu - numeryczny model wysokościowy terenu oraz numeryczny model szorstkości terenu. Modele zostały wykonane w oprogramowaniu GIS - Global Mapper.

Numeryczny model wysokościowy terenu został wykonany na podstawie danych SRTM-3 (Shuttle Radar Topography Mission). Dane Shuttle Radar Topography Mission pochodzą z misji przeprowadzonej przez Narodową Agencję Aeronautyki i Przestrzeni Kosmicznej Stanów Zjednoczonych (NASA), której celem było zebranie danych do opracowania globalnego numerycznego modelu terenu. Dane zostały zebrane metodą interferometrii radarowej $\mathrm{z}$ poziomu promu kosmicznego Endeavour. Dla obszaru odpowiadającego położeniu Polski, dane SRTM-3 cechują się rozdzielczością wynoszącą $60 \mathrm{~m} \times 90 \mathrm{~m}$ [4].

Surowe dane SRTM-3 pozyskane z serwerów NASA zostały poddane analizie w oprogramowaniu GIS - Global Mapper. Zasięg użytego modelu obejmował swoim zasięgiem obszar $625 \mathrm{~km}^{2}$. Rysunek 7 przedstawia próbkę numerycznego modelu wysokościowego terenu $[4,17]$.

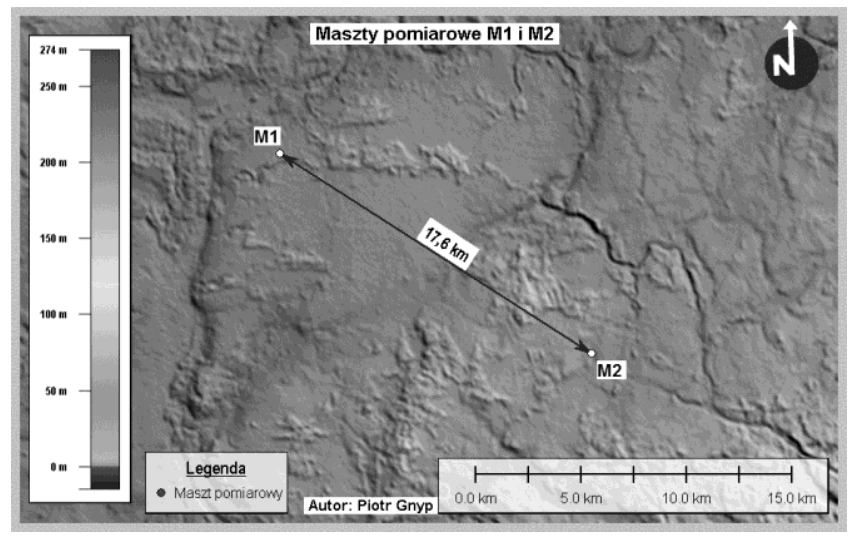

Rys. 7. Próbka numerycznego modelu wysokościowego terenu

Numeryczny model szorstkości terenu opracowano na podstawie danych dotyczących pokrycia terenu pozyskanych z serwerów Europejskiej Agencji Ochrony Środowiska (EEA). Europejska Agencja Ochrony Środowiska publikuje dane dotyczące pokrycia terenu pod nazwą Corine Land Cover. Dane Corine Land Cover dotyczą zmian w pokryciu terenu w latach 2006-2012. Do wygenerowania numerycznego modelu szorstkości terenu wykorzystano dane z 2012 roku. Analiza szorstkości terenu została wykonana w oprogramowaniu GIS Global Mapper. Odpowiednim obszarom zostały przyporządkowane wartości odpowiadające długości szorstkości. Rozdzielczość modelu to $100 \mathrm{~m} \times 100 \mathrm{~m}$. Całkowity zasięg numerycznego model szorstkości terenu obejmował swoim zasięgiem obszar $3025 \mathrm{~km}^{2}$. Rysunek 8 przedstawia próbkę numerycznego modelu szorstkości terenu $[1,18]$. 


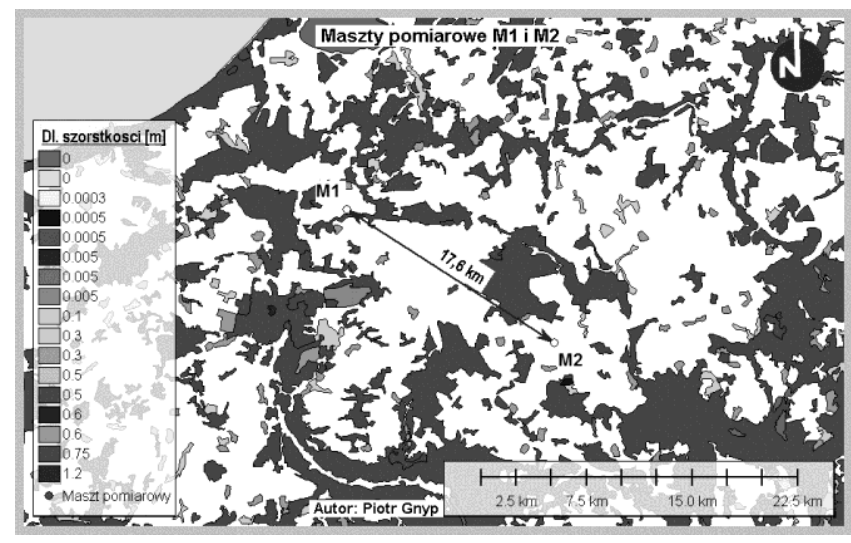

Rys. 8. Próbka numerycznego modelu szorstkości terenu

\section{Metodologia obliczeń}

Do poznania parametrów charakteryzujących wiatr, niezbędne jest zastosowanie metod statystycznych. Do statystycznej metody opisu wiatru stosuje się rozkład Weibulla, który przedstawia prawdopodobieństwo wystąpienia danej prędkości wiatru. Rozkład Weibulla jest funkcją, którą cechują dwa parametry, parametr kształtu (k) oraz parametr skali (A). Rozkład Weibulla zapisuje się przy pomocy równania $[2,8]$ :

$$
f(v)=\frac{k}{A}\left(\frac{v}{A}\right)^{k-1} \cdot \exp \left(-\left(\frac{v}{A}\right)^{k}\right)
$$

gdzie: $\mathrm{f}(\mathrm{v})$ - gęstość prawdopodobieństwa wystąpienia wiatru o wartości prędkości v, k - parametr kształtu, A - parametr skali.

Parametr k określa kształt rozkładu Weibulla. Niskie wartości parametru k charakteryzują miejsca o dużej zmienności warunków wiatrowych (przeważnie sa wartości mieszczace się w przedziale 1,0-1,5). Wyższe wartości parametru $\mathrm{k}$ wskazują na lokalizacje cechujace się stabilnością warunków wiatrowych. Wysokie wartości parametru k $(2,5-3,0)$ określają lokalizacje o najlepszych walorach do lokalizowania siłowni wiatrowych $[2,8]$. Na rysunku 9 przedstawiono przykłady rozkładu Weibulla dla różnych wartości parametru k. Skumulowany rozkład Weibulla wyraża się poprzez poniższy wzór [2]:

$$
F(v)=\exp \left(-\left(\frac{v}{A}\right)^{k}\right)
$$

gdzie: $\mathrm{F}(\mathrm{v})$ - prawdopodobieństwo wystąpienia prędkości wiatru o wartości v, k - parametr kształtu, A - parametr skali.

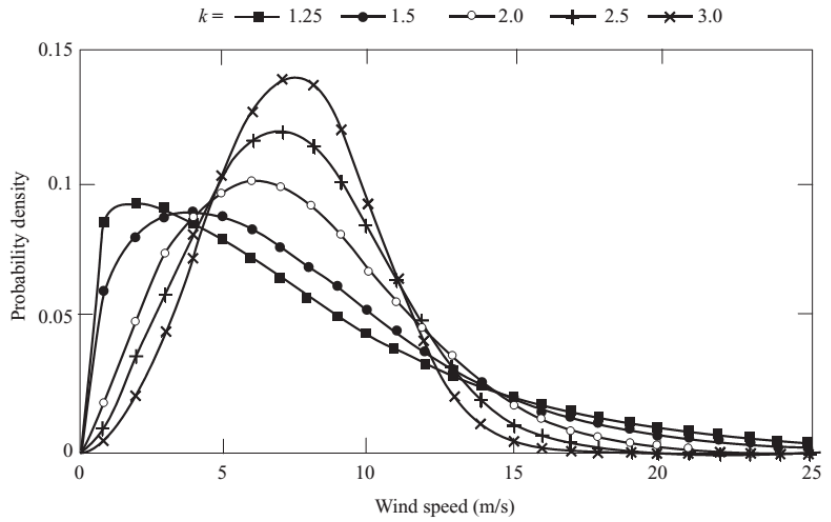

Rys. 9. Przykłady rozkładu Weibulla dla różnych wartości parametru k [8]

Bardzo ważnym parametrem charakteryzującym wiatr jest jego profil obrazujący zmiany prędkości wraz ze zmianą wysokości. Dzięki zastosowaniu anemometrów zainstalowanych na różnych wysokościach masztu pomiarowego można wyznaczyć jego oczekiwany przebieg. Przebieg profilu wiatru jest silnie determinowany przez ukształtowanie i pokrycie terenu. Wysokie wartości szorstkości terenu powodują szybsze wyhamowywanie i spiętrzenie napływającej masy powietrza.
Profil wiatru można wyznaczyć przy użyciu równania [6]:

$$
\frac{v_{1}\left(z_{1}\right)}{v_{2}\left(z_{2}\right)}=\left(\frac{\ln z_{1}-\ln z_{0}}{\ln z_{2}-\ln z_{0}}\right)
$$

gdzie: $\mathrm{v}_{1}$ - zmierzona prędkość wiatru, $\mathrm{v}_{2}$ - prędkość wiatru $\mathrm{W}$ osi siłowni wiatrowej, $\mathrm{z}_{1}-$ wysokość wykonania pomiaru, $\mathrm{z}_{2}$ - wysokość do osi siłowni wiatrowej, $\mathrm{z}_{0}$ - parametr określający szorstkość terenu.

\section{Wyniki badań}

Podczas analizy danych o wietrzności pochodzacych $\mathrm{z}$ masztów pomiarowych M1 i M2 wyznaczono główne parametry rozkładu wiatru. Wyznaczono średnioroczne i średniomiesięczne prędkości wiatru oraz średnią prędkość wiatru z całego okresu pomiarowego. Wyznaczono parametry rozkładu Weibulla (parametr k oraz A) oraz profile wiatru. Rysunek 10 przedstawia próbkę danych z masztów pomiarowych M1 i M2. W tabelach 3 i 4 zestawiono rozkłady prędkości wiatru dla masztów pomiarowych M1 i M2 dla wysokości 100 m. Rozkład parametrów Weibulla dla masztów pomiarowych M1 i M2 przedstawiono w tabelach 5 i 6 . Rysunek 11 ilustruje obliczone profile wiatru dla masztów pomiarowych M1 i M2.

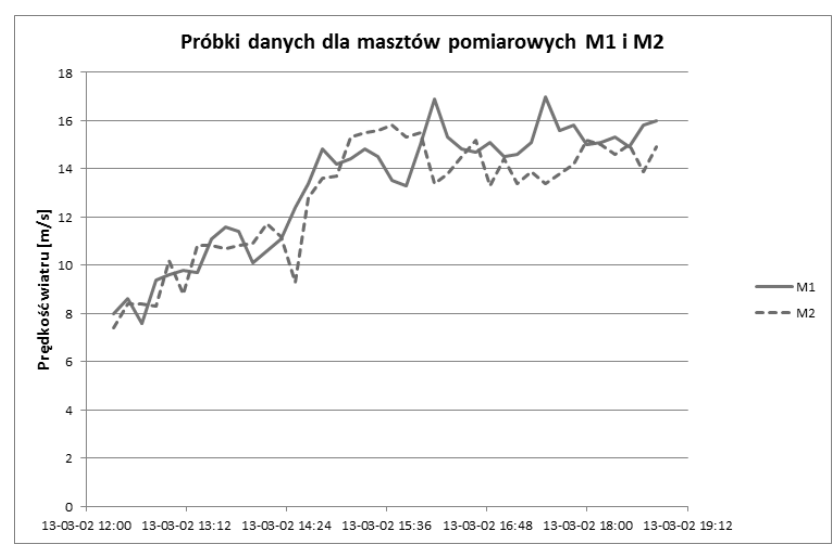

Rys. 10. Próbki danych z masztów pomiarowych M1 i M2

Tabela 3. Rozkład prędkości wiatru dla masztu pomiarowego M1 dla wys. $100 \mathrm{~m}$

\begin{tabular}{|c|c|c|c|c|}
\hline \multirow{2}{*}{ Miesiąc } & \multicolumn{4}{|c|}{ Maszt pomiarowy M1 } \\
\cline { 2 - 5 } & 2011 & 2012 & 2013 & 2014 \\
\cline { 2 - 5 } & \multicolumn{4}{|c|}{ Prędkość wiatru v [m/s] } \\
\hline Styczeń & - & 8,54 & 6,92 & 8,65 \\
\hline Luty & - & 7,73 & 5,82 & 8,24 \\
\hline Marzec & 7,58 & 7,52 & 6,76 & 7,36 \\
\hline Kwiecień & 7,57 & 6,72 & 6,88 & 6,53 \\
\hline Maj & 6,70 & 6,84 & 5,91 & 6,61 \\
\hline Czerwiec & 6,46 & 6,38 & 5,64 & 5,76 \\
\hline Lipiec & 5,67 & 5,89 & 5,82 & - \\
\hline Sierpień & 7,13 & 5,90 & 5,97 & - \\
\hline Wrzesień & 7,50 & 7,44 & 6,29 & - \\
\hline Październik & 7,73 & 7,17 & 7,37 & - \\
\hline Listopad & 7,38 & 7,47 & 7,33 & - \\
\hline Grudzień & 9,35 & 7,41 & 8,91 & - \\
\hline $\mathbf{V}_{\text {srrrok }}$ & 7,31 & 7,08 & 6,64 & 7,19 \\
\hline $\mathbf{V}_{\text {srrcaty okres }}$ & \multicolumn{5}{|c|}{7,05} \\
\hline
\end{tabular}

Tabela 4. Rozkład prędkości wiatru dla masztu pomiarowego M2 dla wys. $100 \mathrm{~m}$

\begin{tabular}{|c|c|c|c|c|}
\hline \multirow{2}{*}{ Miesiąc } & \multicolumn{4}{|c|}{ Maszt pomiarowy M2 } \\
\cline { 2 - 5 } & 2011 & 2012 & 2013 & 2014 \\
\cline { 2 - 5 } & \multicolumn{4}{|c|}{ Prędkość wiatru v [m/s] } \\
\hline Styczeń & - & 7,48 & 6,49 & 7,59 \\
\hline Luty & - & 7,18 & 5,50 & 7,07 \\
\hline Marzec & 7,26 & 7,16 & 6,50 & 6,87 \\
\hline Kwiecień & 7,02 & 6,29 & 6,35 & 5,92 \\
\hline Maj & 6,13 & 6,32 & 5,47 & 6,25 \\
\hline Czerwiec & 6,06 & 5,91 & 5,33 & 5,41 \\
\hline Lipiec & 5,39 & 5,42 & 5,54 & - \\
\hline Sierpień & 6,39 & 5,45 & 5,46 & - \\
\hline Wrzesień & 6,72 & 6,74 & 5,75 & - \\
\hline Październik & 6,96 & 6,49 & 6,63 & - \\
\hline Listopad & 6,35 & 6,63 & 6,79 & - \\
\hline Grudzień & 8,72 & 7,02 & 8,11 & 6,52 \\
\hline $\mathbf{V}_{\text {srr } r \text { rok }}$ & 6,70 & 6,51 & 6,16 & \\
\hline $\mathbf{V}_{\text {srrcaty okres }}$ & \multicolumn{5}{|c|}{6,47} \\
\hline
\end{tabular}


Tabela 5. Parametry rozkładu wiatru dla masztu pomiarowego M1 na wys. $100 \mathrm{~m}$

\begin{tabular}{|c|c|c|c|c|}
\hline Kierunek & $\begin{array}{c}\text { Parametr A } \\
{[-]}\end{array}$ & $\begin{array}{c}\text { Parametr k } \\
{[-]}\end{array}$ & $\begin{array}{c}\text { Śr. prędkość } \\
\text { wiatru [m/s] }\end{array}$ & $\begin{array}{c}\text { Częstotliwość } \\
\text { występowania [\%] }\end{array}$ \\
\hline N & 5,93 & 2,033 & 5,25 & 5,1 \\
\hline NNE & 6,28 & 2,774 & 5,59 & 5,6 \\
\hline ENE & 6,76 & 2,716 & 6,01 & 6,0 \\
\hline E & 7,25 & 3,052 & 6,48 & 5,3 \\
\hline ESE & 8,26 & 3,334 & 7,41 & 6,3 \\
\hline SSE & 8,58 & 3,980 & 7,78 & 9,4 \\
\hline S & 8,28 & 3,848 & 7,49 & 9,3 \\
\hline SSW & 8,18 & 3,743 & 7,38 & 10,4 \\
\hline WSW & 8,64 & 3,250 & 7,75 & 14,9 \\
\hline W & 9,13 & 2,281 & 8,09 & 15,8 \\
\hline WNW & 7,04 & 1,819 & 6,26 & 7,1 \\
\hline NNW & 6,12 & 2,006 & 5,43 & 4,8 \\
\hline Średnia & 7,98 & 2,620 & 7,09 & 100,0 \\
\hline
\end{tabular}

Tabela 6. Parametry rozktadu wiatru dla masztu pomiarowego M2 na wys. $100 \mathrm{~m}$

\begin{tabular}{|c|c|c|c|c|}
\hline Kierunek & $\begin{array}{c}\text { Parametr A } \\
{[-]}\end{array}$ & $\begin{array}{c}\text { Parametr k } \\
{[-]}\end{array}$ & $\begin{array}{c}\text { Śr. prędkość } \\
\text { wiatru [m/s] }\end{array}$ & $\begin{array}{c}\text { Częstotliwość } \\
\text { występowania [\%] }\end{array}$ \\
\hline N & 6,13 & 2,539 & 5,44 & 5,2 \\
\hline NNE & 6,19 & 2,616 & 5,50 & 5,5 \\
\hline ENE & 6,39 & 2,950 & 5,70 & 6,4 \\
\hline E & 6,45 & 2,884 & 5,75 & 4,9 \\
\hline ESE & 6,64 & 3,052 & 5,94 & 5,7 \\
\hline SSE & 6,90 & 3,348 & 6,19 & 9,1 \\
\hline S & 7,24 & 3,209 & 6,49 & 10,9 \\
\hline SSW & 7,60 & 3,372 & 6,82 & 10,7 \\
\hline WSW & 7,98 & 2,947 & 7,12 & 15,0 \\
\hline W & 8,54 & 2,176 & 7,56 & 15,4 \\
\hline WNW & 7,06 & 1,925 & 6,26 & 7,0 \\
\hline NNW & 6,41 & 2,436 & 5,69 & 4,6 \\
\hline Średnia & 7,30 & 2,548 & 6,48 & 100,0 \\
\hline
\end{tabular}

Profile wiatru dla masztów pomiarowych M1 i M2

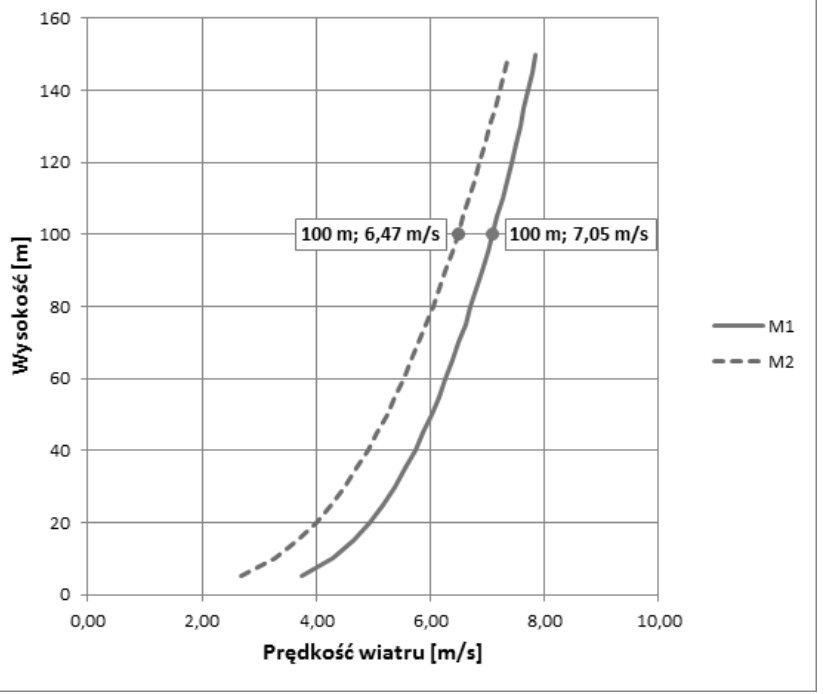

Rys. 11. Obliczone profile wiatru dla masztów pomiarowych M1 i M2

\section{Podsumowanie}

W wyniku przeprowadzonej analizy zauważono, że mimo małej odległości pomiędzy masztami pomiarowymi M1 i M2, wynoszącej $17,6 \mathrm{~km}$, prędkości wiatru były zauważalnie różne. Różnica w zmierzonej prędkości wiatru, z całego okresu pomiarowego, na wysokości $100 \mathrm{~m}$ wyniosła $0,58 \mathrm{~m} / \mathrm{s}$.

Odnosząc tą wartość do przebiegu krzywej mocy siłowni wiatrowej, prognozowana produktywność energetyczna może znacząco się różnić. Zakładając, że przy średniorocznej prędkości wiatru na poziomie $7,05 \mathrm{~m} / \mathrm{s}$ (warunki dla masztu pomiarowego M1) i gęstości powietrza $1,225 \mathrm{~kg} / \mathrm{m}^{3}$ siłownia wiatrowa Vestas V100 o mocy nominalnej generatora 1,8 MW jest w stanie wygenerować $6563 \mathrm{MWh}$ rocznie, natomiast dla średniorocznej prędkości wiatru wynoszącej $6,47 \mathrm{~m} / \mathrm{s}$ (warunki dla masztu pomiarowego M2) siłownia ta wygeneruje $4891 \mathrm{MWh}$ rocznie.

Różnica w prędkości wiatru o $0,58 \mathrm{~m} / \mathrm{s}$ oznaczać będzie zmianę W wytwarzaniu energii elektrycznej na poziomie $1582 \mathrm{MWh} /$ rok $(24,1 \%)$ [15].

Średni kierunek wiatru był porównywalny, nie odnotowano znaczących odchyleń. Dla masztu pomiarowego M1 średni kierunek wiatru $\mathrm{z}$ całego okresu pomiarowego wynosił $228,1^{\circ}$, dla masztu M2 wyniósł $226,1^{\circ}$. Różnica w zmierzonym kierunku wiatru na wysokości $100 \mathrm{~m}$ pomiędzy masztami M1 i M2 wyniosła $2^{\circ}$

Eksperyment mający na celu wykazanie różnic w charakterze wietrzności dla dwóch bliskich lokalizacji pokazał, że ukształtowanie i pokrycie terenu mają wpływ na przepływająca masę powietrza. Niewielkie różnice w zmierzonej prędkości wiatru mogą mieć istotny wpływ na planowaną produktywność energetyczną projektowanej farmy wiatrowej.

Przed podjęciem decyzji o wykonaniu pomiarów wietrzności dla danej lokalizacji należy przeanalizować ukształtowanie i pokrycie terenu. Dla zróżnicowanych obszarów okazać się może, że dodatkowy pomiar wietrzności będzie niezbędny dla wykonania prawidłowej prognozy, gwarantującej efektywniejsze wykorzystanie zasobów wiatru.

\section{Literatura}

[1] Bossard, M., Feranec, J. i Otahel, J.: CORINE land cover technical guide Addendum 2000. EEA, Copenhagen 2000.

[2] Gnyp, P.: Analiza warunków wiatrowych na przykładzie masztu pomiarowego Grapice (województwo pomorskie. Przegląd Naukowy - Inżynieria Kształtowanie Środowiska, 2015/Vol. 24, 391-399.

[3] Lorenc, H. Struktura i zasoby energetyczne wiatru w Polsce. IMiGW, Warszawa 1996.

[4] Karwel, A.: Ocena dokładności modelu SRTM na obszarze Polski. Archiwum Fotogrametrii, Kartografi i i Teledetekcji, 2006/Vol. 16, 289-291.

[5] Kowalczyk, E. i Kowalczyk, R.: Inwestuję w elektrownię wiatrową. Poligraf, Brzezia Łaka k. Wrocławia 2009.

[6] Majewski, G., Nasiłkowska, B.: Energia wiatru - ocena zasobów i problemy inwestycji w odnawialne źródła energii na przykładzie gminy Latowicz (woj. mazowieckie. Przegląd Naukowy - Inżynieria i Kształtowanie Środowiska, 2011/Vol. 20, 61-71.

[7] Nielsen, P.: WindPRO 2.8 User Guide. EMD International A/S, Aalborg 2012

[8] Tony Burton, T., David Sharpe, D., Nick Jenkins, N. i Ervin Bossanyi, E.: Wind Energy Handbook. John Wiley \& Sons, West Sussex 2001.

[9] Tytko, R.: Odnawialne źródła energii. OWG, Warszawa 2010.

[10] PN-EN 61400-12-1:2006:2006-07-26. Turbozespoły wiatrowe -- Cześś 12-1 Pomiary własności energetycznych wiatrowych turbozespołów prądotwórczych.

[11] www.ammonit.com/images/stories/downloadpdfs/datasheets/anemometers/anemometer_thiesfirstclassadvanced_s11100h.pdf [09.05.2017]

[12] www.ammonit.com/images/stories/downloadpdfs/datenblaetter/01_datenlogger/en_ds_datalogger_meteo-32.pdf [09.05.2017]

[13] www.ammonit.com/images/stories/downloadpdfs/datasheets/windvanes/windvane_thiescompactpotplug_s22200-s22200h.pdf [09.05.2017]

[14] www.measnet.com/wp-

content/uploads/2016/05/measnet_siteassessment_v2.0.pdf [18.11.2016]

[15] www.vestas.com/en/system/links/media-links/productmedia/brochures/uk/2mw-product-brochure [06.10.2015]

[16] www.geoportal.gov.pl/ [15.04.2017]

[17] dds.cr.usgs.gov/srtm/version2_1/SRTM3/Eurasia/ [27.04.2017]

[18] land.copernicus.eu/pan-european/corine-land-cover/clc-2012 [27.04.2017]

\section{Mgr inż. Piotr Gnyp}

e-mail: piotr.gnyp@ hotmail.com

Doktorant na Wydziale Inżynierii Środowiska Energetyki Politechniki Śląskiej. Absolwent Wydziału Inżynierii Procesowej i Ochrony Środowiska Politechnika Łódzkiej.

Od 2009 roku związany zawodowo $\mathrm{z}$ branżą energetyczna, w szczególności przy projektowaniu, zarządzaniu i rozliczaniu inwestycji w obszarze odnawialnych źródeł energii.

Zrealizowane projekty w obszarze energetyki wiatrowej na łączną moc zainstalowaną wynoszącą około $200 \mathrm{MW}$.

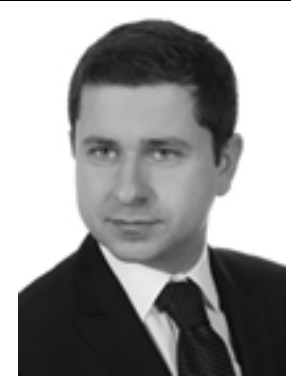

